\title{
EHMTI-0232. Non-surgical management of rhinogenic contact point headache
}

\author{
N Ahmady Roozbahany ${ }^{1 *}$, S Nasri ${ }^{2}$ \\ From 4th European Headache and Migraine Trust International Congress: EHMTIC 2014 \\ Copenhagen, Denmark. 18-21 September 2014
}

\section{Introduction}

Rhinogenic contact point headache (RCPH) is a pain that arises from two opposing mucosal surfaces in the nose. The diagnosis is made by history and physical examination along with nasal endoscopy and imaging. The mainstay of treatment is surgical removal of contact area.

\section{Aims}

To evaluate the effectiveness of non-surgical managements including behavioral and pharmacotherapy in treatment of $\mathrm{RCPH}$.

\section{Methods}

Thirty patients with confirmed diagnosis of RCPH underwent non-surgical management of RCPH using recommendations for absolute contralateral nostril breathing during the pain period, applying warm cushion and medical treatment with non-steroidal analgesics and beta blocker. The results of treatment compared with the results of a group of patients who underwent surgical management.

\section{Results}

More than eighty six percent of patients experienced a significant relief in the severity of the pain. In contrast to the surgically managed group, the frequency of headaches was not altered.

\section{Conclusion}

Non-surgical management of RCPH may have a role in patients who do not accept surgery or are not a candidate for surgical management.

No conflict of interest.

${ }^{1}$ Otolaryngology, Shahid Beheshti Medical University, Tehran, Iran

Full list of author information is available at the end of the article

\author{
Authors' details \\ 'Otolaryngology, Shahid Beheshti Medical University, Tehran, Iran. ${ }^{2}$ Public \\ Health, Private Practice, Tehran, Iran.
}

Published: 18 September 2014

doi:10.1186/1129-2377-15-S1-C1

Cite this article as: Roozbahany and Nasri: EHMTI-0232. Non-surgical

management of rhinogenic contact point headache. The Journal of Headache and Pain 2014 15(Suppl 1):C1.

\section{SpringerOpen ${ }^{\odot}$}

(0) 2014 Roozbahany and Nasri; licensee Springer. This is an Open Access article distributed under the terms of the Creative Commons Attribution License (http://creativecommons.org/licenses/by/2.0), which permits unrestricted use, distribution, and reproduction in any medium, provided the original work is properly cited.
Submit your manuscript to a SpringerOpen ${ }^{\circ}$ journal and benefit from:

- Convenient online submission

- Rigorous peer review

- Immediate publication on acceptance

- Open access: articles freely available online

- High visibility within the field

- Retaining the copyright to your article

Submit your next manuscript at $\boldsymbol{~ s p r i n g e r o p e n . c o m ~}$ 